\title{
Time to put the Internet in perspective
}

\author{
By Kristin Jacobsen
}

The Internet may seem new, but it began over 30 years ago

$\mathbf{T}$ he Internet has virtually exploded into the public consciousness in the last few years. It has made the pages of the New York Times, the Wall Street Journal, and countless other newspapers, and it has been featured as the cover story in Time, Business Week, the Nation, and the New Republic. Those who had never heard of the Internet before last year might believe, incorrectly, that it is essentially an overnight success, a conception that could lead to a faulty understanding of the Internet. To help our patrons at Northwestern University Libraries have a more accurate mental model of the Internet, I created an Internet timeline that illustrates the major events shaping its development.

Most media portrayals of the Internet focus on its possibilities and applications, a valid strategy when trying to explain an unknown and powerful phenomenon. Many mention that this network of networks started as a Department of Defense project to design a decentralized communications network that could withstand nuclear attack. They normally do not have the space, however, to describe its evolution over the course of more than 30 years. In the decades of this evolution, the original ARPANET has grown far beyond its original purpose. It has been shaped and molded by its users to meet far different needs than originally envisioned, a process that continues today in many ways.

This timeline originally served as background material during a one-hour presentation at an alumni continuing education program and later at a workshop for graduate management students on business uses of the Internet. We have also made it available in the Reference Department's Electronic Reference Center, along with a selection of books and journals on the Internet and on information technology.

Many events could be included in a timeline about the development of the Internet. I decided that important aspects to concentrate on were the exponential growth of the Internet; the creation of major structural elements and navigational tools such as gopher, Veronica, and Mosaic; examples of legislation concerning the Internet; and other events that have had an impact on the Internet or that came about because of it.

As we continue to explore ways to demystify the Internet, we look to put it in a context that makes sense in our patrons' lives. We want patrons to understand not only what the Internet is, but how it developed, where it is going, and what significance it will have for them and for society as a whole. I hope that this timeline provides the beginnings of a framework for understanding the Internet and its impact on society. 


\section{Internet timeline}

1964

1969

early 1970 s

1971

1973

1979

1981

1983

1984

mid-1980s

1986

1987

1989

1990

1991

- Paul Baran at RAND designs a packet-switching network to survive nuclear attack. Message is broken down into units of equal size, routed along a functional path, then reassembled at the destination.

- Department of Defense commissions ARPANET, a decentralized network built so that messages could be rerouted in the event that part of the communications system was destroyed by nuclear attack.

- Ethernet, a high-speed network, is developed at Xerox Palo Alto Research Center (PARC). It provides the basis for local area networks (LANs).

- 15 nodes (23 hosts) are online.

- First international ARPANET connections are established to England and Norway.

- Usenet originates at Duke University and the University of North Carolina.

- BITNET ("Because It's Time (There) NETwork") starts as a network at City University of New York and offers a method for scholarly discussion for academics not involved in the sciences.

- ARPANET splits into ARPANET for research and MILNET for military operations.

- TCP/IP, computer code for communicating with the Internet, is developed at the Univ. of California, funded by ARPA, and built into Berkeley Unix.

- Number of hosts surpasses 1,000.

- Network of networks-including ARPANET, MILNET, BITNET, and others-is referred to as ARPA Internet, then simply Internet.

- National Science Foundation (NSF) creates NSFNET to connect 5 supercomputer centers for scholarly research. It becomes the Internet backbone.

- Number of hosts surpasses 10,000.

- NSF signs contracts with IBM, MCI, and Merit Network, Inc., to manage and upgrade NSFNET, the Internet backbone.

- Number of hosts surpasses $\mathbf{1 0 0 , 0 0 0 \text { . }}$

- Staff and students at McGill University in Quebec develop Archie to help keep track of free software from anonymous ftp sites.

- ARPANET is decommissioned.

- Initial World Wide Web (WWW) prototype is developed by CERN, European Particle Physics Laboratory in Switzerland. It allows a user to browse and select links that bring text, graphics, audio, or video on screen.

- Hytelnet, a hypertext browser for telnet-accessible sites, is developed by Peter Scott of the University of Saskatchewan to provide a method for users to browse and select from lists of Internet resources.

- Electronic Frontier Foundation is founded by Mitch Kapor of Lotus.

- "Team Gopher" at the University of Minnesota develops gopher to help the campus community find answers to computer-related questions. 
- WAIS (Wide-Area Information Server) is distributed by Thinking Machines Corporation in Menlo Park, California, to provide "a dynamic hypertext system," a method of searching a wide variety of types of information from a wide variety of sources by asking a question instead of typing in key words. WAIS also allows searches to be refined to produce more relevant results.

- WWW is released on central CERN machines.

- NSF lifts restrictions against commercial use of the Internet. Commercial Internet Exchange (CIX) Association, Inc., is formed by General Atomics (CERFnet), Performance Systems International (PSInet), and UUNET Technologies, Inc. (AlterNet).

- President George Bush signs into law the High Performance Computing Act providing $\$ 650$ million in new spending by the NSF, $\$ 388$ million by DARPA, and $\$ 31$ million by the Department of Commerce's National Institute of Standards and Technology.

- Number of hosts surpasses $1,000,000$.

- Line mode browsing of WWW is made available by anonymous ftp.

- President Bill Clinton announces plans to develop a national electronic infrastructure through government and private efforts, with most government support going to the National Research and Education Network (NREN).

- The University of Nevada development team introduces Veronica to allow subject searching on gopher.

- The Internet Society is chartered

- Rick Gates, then director of library automation for the University of California, Santa Barbara, starts the Internet Hunt.

- Number of hosts surpasses 2,000,000.

- NSF releases plans to restructure Internet by redirecting regional network subsidies to colleges for network fees. Internet to be privately managed under government contract. Eight regional networks form the for-profit Corporation for Regional and Enterprise Networking (CoREN).

- InterNIC is created to provide Internet resources and services. Contracts awarded for: directory and database services (AT\&T); registration services (Network Solutions, Inc.); information services (General Atomics)

- "Internet Talk Radio" begins broadcasting.

- President Bill Clinton signs the Government Printing Office Electronic Access Act to provide online access of federal documents, including the Federal Register, the Congressional Record, and other sources distributed through the Government Printing Office.

- The National Information Infrastructure Act is introduced into the House of Representatives and passes. Its companion bill, the National Competitiveness Act, is introduced into the Senate. The Senate bill is designed to update the High Performance Computing Act of 1991 by focusing on the provision of applications rather than on high-speed networks.

- Mosaic is developed by the National Center for Supercomputing Applications in Champaign, Illinois. It allows use of WWW to browse and click or select links that bring text, graphics, audio, or video to the screen.

- The White House receives e-mail connections.

- The White House announces the formation of the National Information Infrastructure Testbed, an industry/government coalition to develop applications for the Internet, including remote research collaboration 
and medical consulting. Members include AT\&T, Sprint, Hewlett Packard, Digital Equipment Corporation, the University of California at Berkeley, Oregon State University, and the Department of Energy.

- Number of hosts surpasses 3,800,000.

- Vice-President Gore conducts computer-based news conference from the White House.

- The National Competitiveness Act is approved by Senate

- The U.S. Postal Service is asked by Vice-President Gore's National Performance Review to explore the delivery of federal information electronically via kiosks in post offices.

- The U.S. Senate and House of Representatives mount gopher servers.

- Netscape, a WWW browser, is introduced by Mosaic Communications Corporation, a company formed by Jim Clark, founder of Silicon Graphics, Inc,; Mark Andreessen, one of the developers of Mosaic; and other Mosaic developers from the National Center for Supercomputing Applications. Mosaic Communications Corporation later changes its name to Netscape Communications Corporation.

- The White House puts home page, "An Interactive Citizens's Handbook," on the WWW. Includes information on the First Family, agencies and commissions of the Executive Branch, White House electronic publications, and virtual tours of the White House, the Old Executive Office, and the First Ladies' Garden.

- Electronic shopping malls, catalogs, and storefronts appear on the Internet.

- Key-word searching becomes available through search engines such as Lycos, WebCrawler, and the World Wide Web Worm.

- Number of hosts surpasses 4,800,000.

\section{References}

Dern, Daniell P. Internet Guide for New Users. New York: McGraw Hill, 1994.

Duffy, Caroline. "Never Too Soon for a Trial Run: National Information Infrastructure Testbed Unveiled." PC Week 22 (November 1993): N1. Elmer-Dewit, Philip. "First Nation in Cyberspace." Time 6 (December 1993): 62-64.

"Interactive Citizens' Handbook." White House home page online. Available at World Wide Web: http://www. whitehouse.gov.

Internet Domain Survey. (January 1995.) Available at World Wide Web: http://www.nw. $\mathrm{com} /$ zone/WWW/report.html.

Krol, Edward. The Whole Internet: Users Guide and Catalog. Sebastopol, Calif.: O'Reilly \& Associates, 1992.

McDonald, Gary. 1993 network news roundup. MOREnet User's Discussion List [Missouri Research and Education Network]. (Jan. 4, 1994.) Available at MOUSER-L@more.net.

Netscape home page. Available at World Wide Web: http://home.mcom.com.

Patch, Kimberly. "Calling on Washington: The Industry Girds Up to Steer Development of a National Information Infrastructure." $P C$ Week 1 (November 1993): 91.

_.._. "Coalition Puts NII Testbed into Play." PC Week 10 (January 1994): 21.

Rheingold, Howard. The Virtual Community: Homesteading on the Electronic Frontier. Reading, Mass.: Addison-Wesley Pub., 1993.

Shuler, John A. "Great Expectations, Grand Challenges, Limited Opportunities: National Information Infrastructure." Computers in Libraries 13 (October 1993): 46.

Stuivenga, Will. Postal Service and Information Superhighway. Public-Access Computer Systems Forum. (June 1, 1994.) Available at: PACS-L@uhupvm1.uh.edu.

U.S. House of Representatives Gopher. Available at gopher: gopher.house.gov.

U.S. Senate Gopher. Available at gopher: gopher senate.gov/ 1 .

WWW "History to Date." Available at telnet: info.cern.ch.

Zakon, Robert Hobbes. "Hobbes's Internet Timeline v1.1." Available at: timeline@hobbes.mitre. org. Auto reply sends timeline. For questions send e-mail to: hobbes@hobbes.mitre.org. 